\title{
Palmer Amaranth (Amaranthus palmeri) Growth and Seed Production When in Competition with Peanut and Other Crops in North Carolina
}

\author{
Denis J. Mahoney ${ }^{1}$, David L. Jordan ${ }^{1, *}$, Andrew T. Hare ${ }^{1}$, Ramon G. Leon ${ }^{1} \mathbb{D}$, Nilda Roma-Burgos ${ }^{2} \mathbb{D}$, \\ Matthew C. Vann ${ }^{1}\left(\mathbb{D}\right.$, Katherine M. Jennings ${ }^{3}$, Wesley J. Everman ${ }^{1}$ and Charles W. Cahoon ${ }^{1}$
}

1 Department of Crop and Soil Sciences, North Carolina State University, Campus Box 7620, Raleigh, NC 27695, USA; djmahone@ncsu.edu (D.J.M.); athare@ncsu.edu (A.T.H.); rleon@ncsu.edu (R.G.L.); matthew_vann@ncsu.edu (M.C.V.); wes_everman@ncsu.edu (W.J.E.); charlie_cahoon@ncsu.edu (C.W.C.)

2 Department of Crop, Soil, and Environmental Sciences, University of Arkansas, Fayetteville, AR 72701, USA; nburgos@uark.edu

3 Department of Horticultural Science, North Carolina State University, Raleigh, NC 27695, USA; kmjennings@ncsu.edu

* Correspondence: david_jordan@ncsu.edu; Tel.: +1-919-810-6611

check for updates

Citation: Mahoney, D.J.; Jordan, D.L.; Hare, A.T.; Leon, R.G.; Roma-Burgos, N.; Vann, M.C.; Jennings, K.M.; Everman, W.J.; Cahoon, C.W. Palmer Amaranth (Amaranthus palmeri) Growth and Seed Production When in Competition with Peanut and Other Crops in North Carolina. Agronomy 2021, 11, 1734. https:/ / doi.org/10.3390/agronomy11091734

Academic Editors:

Emanuele Radicetti and

Rodolfo Gentili

Received: 25 June 2021

Accepted: 23 August 2021

Published: 29 August 2021

Publisher's Note: MDPI stays neutral with regard to jurisdictional claims in published maps and institutional affiliations.

Copyright: (c) 2021 by the authors. Licensee MDPI, Basel, Switzerland. This article is an open access article distributed under the terms and conditions of the Creative Commons Attribution (CC BY) license (https:/ / creativecommons.org/licenses/by/ $4.0 /)$.
Abstract: Palmer amaranth (Amaranthus palmeri S. Wats.) is a highly competitive weed that can be difficult to manage in many cropping systems. Research to date has not quantified the growth and development of $A$. palmeri in a manner that allows direct comparisons across cropping systems. Research was conducted to compare the growth, development, and seed production of $A$. palmeri when competing with corn (Zea mays L.), cotton (Gossypium hirsutum L.), peanut (Arachis hypogaea L.), and soybean [Glycine max (L.) Merr.] when emerging with crops or emerging three weeks after crops emerge. Regardless of when A. palmeri emerged, seed production was greatest and similar in cotton and peanut and exceeded that of corn and soybean; seed production in soybean exceeded that of corn. However, seed production was approximately 10 -fold greater when A. palmeri emerged with crops compared with emergence three weeks later. These results illustrate the importance of controlling weeds during the first three weeks of the season relative to contributions of A. palmeri to the weed seed bank and is the first report comparing seed production in presence of these crops in a manner allowing a statistical comparison of seed production and highlighting the importance of crop sequence for seed bank management.

Keywords: crop competition; fecundity; weed interference

\section{Introduction}

Palmer amaranth (Amaranthus palmeri S. Wats.) is regarded as one of the most problematic weeds in the United States [1]. It possesses robust growth habits [2,3] and has been shown to effectively compete against crops for nutrients [4], light [5], and water [6]. Amaranthus palmeri is an obligate cross-pollinator, which contributes to its high genetic variation [7]. Its pollen can move long distances [8]. Along with immense herbicide selection pressure, these characteristics have led to A. palmeri populations having resistance to several mechanisms of action with some populations expressing multiple resistance $[9,10]$. These competitive characteristics make this weed highly problematic. If not controlled adequately, A. palmeri threatens the economic viability of major agronomic and horticultural crops $[4,5,11,12]$.

Understanding the biology and ecology of weeds is critical in order to mitigate and manage herbicide-resistant populations with particular attention required for weed seedbank dynamics [13]. Previous research has explored some of these aspects with respect to A. palmeri. In Kansas, Horak and Loughin [14] reported that in mid- to late-June emerging A. palmeri height increased from 0.18 to $0.21 \mathrm{~cm}$ growing-degree-day ${ }^{-1}$ (GDD) and reached 
maximum heights greater than $2 \mathrm{~m}$. When a second cohort emerged approximately three weeks later, height increases were 0.11 to $0.17 \mathrm{~cm} \mathrm{GDD}^{-1}$ with a maximum height of $174 \mathrm{~cm}$. In Indiana, Spaunhorst et al. [3] described a similar growth rate of 0.14 to $0.17 \mathrm{~cm} \mathrm{GDD}^{-1}$ for regionally distinct $A$. palmeri accessions, not competing with crops, when emerging in mid-June. When $A$. palmeri is growing without competition, it can reach heights of 160 to $269 \mathrm{~cm}$ and produce over 613,000 seeds female ${ }^{-1}[2,3,14,15]$. When in competition with cotton in Arkansas, A. palmeri emerging 0 and $3 \mathrm{w}$ after cotton reached approximately 138 and $105 \mathrm{~cm}$ in height, respectively [16]. Seed production was still high in these females and was estimated to be 20,000 to 90,000 seeds plant ${ }^{-1}$. In Georgia, male and female A. palmeri attained final heights of approximately 150 and $130 \mathrm{~cm}$ when emerging at 0 and 3 weeks after cotton, respectively [12]. Female plants produced approximately 300,000 and 100,000 seeds plant $^{-1}$ at these emergence timings, respectively.

While the aforementioned studies are informative, important knowledge gaps exist. For example, much of the previous research has been completed when A. palmeri was not growing in competition with crops [2,3,14,15]. Furthermore, the reference studies were primarily located in the mid-southern to western US [2,3,14-16]. Competition studies have been conducted in the southeastern US, but only with one crop [5,11,12] and did not always estimate seed production. Research is also limited with respect to growth and seed production of $A$. palmeri when emerging at various times following a competing crop [12,16]. The need for a "zero-tolerance" policy has increased over time, especially when considering A. palmeri fecundity [17]. To date, research that allows for direct comparison of A. palmeri growth and seed production in competition with multiple crops has not been done. This is information is critical to plan rotations with crop sequences that effectively prevent $A$. palmeri population growth. Therefore, the objectives of this research were to (1) measure the growth of male and female $A$. palmeri plants emerging with and three weeks after corn, cotton, peanut, and soybean; (2) determine the effects of emergence time and duration of interference on $A$. palmeri seed production.

\section{Materials and Methods}

Two field experiments were conducted at the Upper Coastal Plan Research Station (35.9 N-77.7 W) near Rocky Mount, North Carolina (NC) in 2018 using natural A. palmeri populations. Fields were approximately $0.25 \mathrm{~km}$ apart with different soil characteristics and cropping histories including weed management. This population is resistant to both ALS and EPSP synthase-inhibiting herbicides [18,19]. Soils were an Aycock very fine sandy loam (fine-silty, siliceous, subactive, thermic Typic Paleudult) in one field and a Goldsboro fine sandy loam (fine-loamy, siliceous, subactive, thermic Aquic Paleudult) in the other field. Corn (hybrid P1847VYHR, Pioneer Hi-Bred International, Johnson City, IA, USA), cotton (cultivar Delta Pine Bolgard II Xtendiflex, Monsanto Company, St. Louis, MO, USA), peanut [20], and soybean (Credenz 7007LL, BASF Corporation, Research Triangle Park, NC, USA) were planted on 5 June, 2018 on a conventionally tilled field with raised seedbeds spaced $96 \mathrm{~cm}$ apart. Plant populations for these respective crops were approximately 84,000 plants ha ${ }^{-1}, 95,000$ plants ha ${ }^{-1}, 244,000$ plants ha $^{-1}$, and 135,000 plants ha ${ }^{-1}$. Crop populations were determined 2 weeks after planting (WAP). One week after planting, eight $A$. palmeri seedlings (Cohort 1 ) were selected plot $^{-1}$. Selected seedlings were on the seedbed edges approximately $20 \mathrm{~cm}$ from the crop. Additionally, seedlings were spaced to ensure at least a $3 \mathrm{~m}^{2}$ weed-free area for each plant to mitigate intraspecific competition. Plot sizes were 12 rows by 6 to $9.1 \mathrm{~m}$. The experimental design was a randomized complete block design with four replications. Crops were randomized within each replication. The plot layout is represented in Figure 1. 


\begin{tabular}{|c|c|c|c|}
\hline Soybean & Corn & Peanut & Cotton \\
401 & 402 & 403 & 404 \\
\hline Corn & Peanut & Cotton & Soybean \\
301 & 302 & 303 & 304 \\
\hline Cotton & Soybean & Corn & Peanut \\
201 & 202 & 203 & 204 \\
\hline Peanut & Cotton & Soybean & Corn \\
101 & 102 & 103 & 104 \\
\hline
\end{tabular}

Figure 1. Crop and replication arrangement in the field. Within each crop Amaranthus palmeri emerging with the crop or emerging three weeks after the crop emerged were sampled. Plots 101, 102,103 , and 104 constitute a replication.

One week after seedling selection ( 2 WAP), the selected plants were covered with inverted cups and herbicides were applied over the top to control non-selected weeds. Herbicides with no soil residual activity were chosen to avoid unintended effect on the selected plants through root absorption, and to allow for a second flush of $A$. palmeri (Cohort 2) to emerge the following week. The second cohort of $A$. palmeri was selected in a similar fashion at 3 WAP to simulate those escaping a preemergence herbicide. This was done to understand the competitive advantage of crops against later-emerging $A$. palmeri. All selected weeds were then covered, and herbicides were applied to control non-selected weeds. Plots were kept weed-free beyond this date by hand weeding or hoeing. Urea ammonium nitrate $(32 \% \mathrm{~N})$ was applied (approximately 5 to $10 \mathrm{~cm}$ from the crop base) to corn (135 kg N ha $\left.{ }^{-1}\right)$ and cotton $\left(67 \mathrm{~kg} \mathrm{~N} \mathrm{ha}^{-1}\right) 3$ to 4 WAP according to the Cooperative Extension Service recommendations for North Carolina [21,22]. Fertilizer was applied on each side of the crop row from the selected $A$. palmeri plants to prevent physical damage from application equipment. All other pests were controlled using recommended production practices [21-24].

A. palmeri canopy height and width were measured every two weeks following selection throughout the growing season. Measurements for male or female plants were averaged within each plot where more than one plant was present. All plants from Cohort 1 and 2 were harvested approximately 14 and 17 WAP, respectively. Freshly cut shoots were weighed in the field at harvest. Female plants were placed in bags to minimize seed loss, transported to the Method Road Greenhouse Complex (Raleigh, NC, USA), and dried in the greenhouse at 25 to $30 \mathrm{C}$. When dried, seeds were stripped manually and homogenized using a Thomas-Wiley Lab Mill (Thomas Scientific, Swedesboro, NJ, USA) fitted with a $2 \mathrm{~mm}$ sieve. Chaff was then removed similar to Sosnoskie et al. [25], and the total cleaned seed was weighed. The total number of seeds produced was then calculated by averaging the weight of 100 seeds from 5 separate, 100-seed counts and extrapolating the total seed number per plant based on the total seed biomass [15].

Weather data were obtained from a weather station approximately $300 \mathrm{~m}$ from the field and used to calculate growing degree days (GDD). Growth parameters were plotted against GDD (base 10 C) using a four-parameter logistic function in SigmaPlot (SigmaPlot v. 14.0, Systat Software, San Jose, CA, USA), similar to the methodology by Spaunhorst et al. [3]. Growth parameters included canopy height and width as well as percent of maximum heights and widths. Percent of maximum height and width were calculated based on plants from the plot in each replication that were the tallest and widest irrespective of crop. Root mean square error (RSME; Equation (1)) and modeling efficiency coefficients (MEF; Equation (2)) were calculated to test the goodness of fit of the model where $P_{i}$ is the predicted value, $O_{i}$ is the observed value, $n$ is the number of observations, and $O_{i}$ is the mean observed value [26].

$$
R M S E=\left[\frac{1}{n} \sum_{i=1}^{n}\left(P_{i}-o_{i}\right)^{2}\right]^{1 / 2}
$$




$$
M E F=1-\left[\sum_{i=1}^{n}\left(O_{i}-P_{i}\right)^{2} / \sum_{i=1}^{n}\left(O_{i}-O_{i}\right)^{2}\right]
$$

A RMSE value of zero suggests that the predicted and observed values are a perfect fit to the model. An MEF value close to one suggests high accuracy of model predictions. Models were fit by gender and crop for each replication. Following fitting, GDD needed to reach 10,50 , and $90 \%$ of maximum height, which were calculated and analyzed using PROC GLIMMIX in SAS (SAS 9.4, SAS Institute Inc., Cary, NC, USA). Crop and gender were considered fixed effects while replication and field were considered random. Final height, width, shoot biomass, and seed production were analyzed using PROC GLIMMIX. Data for seed production were log-transformed prior to analysis in order to meet the assumptions of normality, but the untransformed data are presented. Means were separated according to Fisher's protected LSD at $\alpha=0.05$. Pearson correlation coefficients were determined using the PROC CORR procedure (SAS 9.4, SAS Institute Inc., Cary, NC, USA).

\section{Results and Discussion}

\subsection{Plant Height}

The logistic models built described the relationship of female (RMSE 8.2 to 11.5, MEF 0.97 to 0.99 ) and male (RMSE 4.0 to 16.1, MEF 0.96 to 1.00) A. palmeri heights in Cohort 1 and GDDs (Table 1). Overall, male and female plants grew similarly in height within their respective crops over the study period (Figure 2). The maximum canopy height of $A$. palmeri was the only response variable affected by crop competition $(p<0.0001, \mathrm{~F}=20.7)$ and gender $(p=0.0008, \mathrm{~F}=11.7)$. Amaranthus palmeri predicted height in corn $(223 \mathrm{~cm})$ was taller than that in cotton $(202 \mathrm{~cm}$ height), followed by that in peanut $(177 \mathrm{~cm})$ and soybean $(177 \mathrm{~cm})$, which were similar. When competing with cotton season long in Arkansas, the final $A$. palmeri heights averaged approximately $138 \mathrm{~cm} \mathrm{[16].} \mathrm{The} \mathrm{seemingly} \mathrm{significant}$ difference in final heights presented by Norsworthy et al. [16] compared to our research may be due to factors including, but not limited to: environmental differences between research sites and/or the overspray of herbicides by Norsworthy et al. [16]. In Georgia, Webster and Grey [12] reported male and female A. palmeri final heights (149 to $166 \mathrm{~cm})$ being similar when competing with cotton season long. A. palmeri attained heights of $177 \mathrm{~cm}$ when competing season long in NC [5]. This maximum height was similar to what A. palmeri attained when in season-long competition with peanut in the current research. Burke et al. [11] also reported a maximum height of $175 \mathrm{~cm}$ of $A$. palmeri competing with peanut season long in NC.
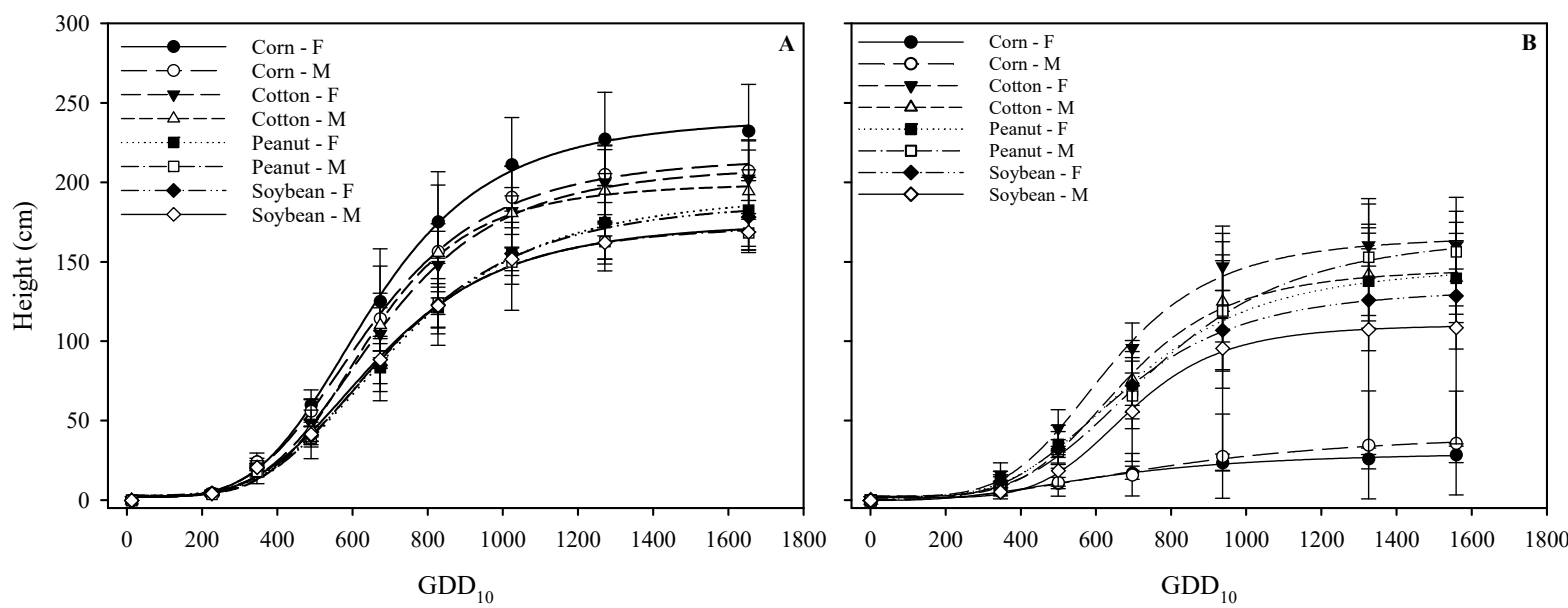

Figure 2. Male (M) and female (F) Palmer amaranth (Amaranthus palmeri) heights modeled against growing degree days (GDD; base $10 \mathrm{C}$ ) when competing with corn, cotton, peanut, and soybean crops. Amaranthus palmeri was allowed to emerge with the crops (Cohort 1; (A)) and three weeks after crop planting (Cohort 2; (B). Parameter estimates for Cohort 1 and Cohort 2 can be found in Table 2. Growing degree day 0 represents crop planting (Cohort 1) or three weeks after crop planting (Cohort 2). Error bars represent 95\% confidence intervals. Data are pooled over two field sites. 
Table 1. Parameter estimates and goodness of fit using the four-parameter logistic function to fit male and female Palmer amaranth (Amaranthus palmeri) height when emerging with (Cohort 1 ) and three weeks after (Cohort 2) with corn, cotton, peanut, and soybean crops ${ }^{a, b}$.

\begin{tabular}{|c|c|c|c|c|c|c|c|}
\hline Crop & Gender & $b^{c}$ & $c^{c}$ & $d^{\mathrm{c}}$ & $\mathrm{GDD}_{50}$ & RMSE $^{d}$ & MEF \\
\hline & & & & $\mathrm{m}-$ & & & \\
\hline \multirow[t]{2}{*}{ Corn } & Female & $4.0 \pm 0.3$ & $2.3 \pm 4.4$ & $241.6 \pm 6.5$ & $653.4 \pm 16.8$ & 11.4 & 0.98 \\
\hline & Male & $3.9 \pm 0.3$ & $2.3 \pm 3.1$ & $217.4 \pm 4.7$ & $648.7 \pm 13.4$ & 8.0 & 0.99 \\
\hline \multirow[t]{2}{*}{ Cotton } & Female & $4.1 \pm 0.3$ & $2.3 \pm 3.2$ & $211.6 \pm 5.0$ & $672.5 \pm 14.6$ & 8.5 & 0.99 \\
\hline & Male & $4.7 \pm 0.7$ & $3.0 \pm 5.8$ & $199.9 \pm 7.6$ & $642.9 \pm 23.5$ & 16.1 & 0.96 \\
\hline \multirow[t]{2}{*}{ Peanut } & Female & $3.7 \pm 0.3$ & $2.4 \pm 3.1$ & $193.8 \pm 6.0$ & $721.0 \pm 19.2$ & 8.2 & 0.99 \\
\hline & Male & $4.1 \pm 0.2$ & $2.5 \pm 1.5$ & $174.4 \pm 2.4$ & $671.8 \pm 8.4$ & 4.0 & 1.00 \\
\hline \multirow[t]{2}{*}{ Soybean } & Female & $3.8 \pm 0.5$ & $3.2 \pm 4.4$ & $189.7 \pm 8.0$ & $705.8 \pm 26.0$ & 11.5 & 0.97 \\
\hline & Male & $3.8 \pm 0.2$ & $2.5 \pm 2.0$ & $176.1 \pm 3.2$ & $668.3 \pm 11.5$ & 5.2 & 0.99 \\
\hline \multirow{3}{*}{ Corn } & & & & -Coho & & & \\
\hline & Female & $2.7 \pm 0.5$ & $0.1 \pm 1.3$ & $30.8 \pm 2.5$ & $628.8 \pm 56.3$ & 2.1 & 0.95 \\
\hline & Male & $2.5 \pm 2.2$ & $0.4 \pm 6.1$ & $43.4 \pm 21.4$ & $798.4 \pm 396.3$ & 10.3 & 0.56 \\
\hline \multirow[t]{2}{*}{ Cotton } & Female & $4.4 \pm 0.4$ & $2.8 \pm 3.6$ & $166.4 \pm 4.0$ & $637.4 \pm 16.0$ & 6.7 & 0.99 \\
\hline & Male & $4.7 \pm 0.8$ & $2.5 \pm 5.2$ & $146.2 \pm 6.0$ & $674.2 \pm 27.0$ & 9.9 & 0.96 \\
\hline \multirow[t]{2}{*}{ Peanut } & Female & $3.9 \pm 0.8$ & $2.3 \pm 6.3$ & $148.2 \pm 9.2$ & $699.8 \pm 40.6$ & 11.5 & 0.95 \\
\hline & Male & $4.0 \pm 0.9$ & $2.4 \pm 6.8$ & $168.0 \pm 12.4$ & $765.8 \pm 47.5$ & 13.0 & 0.95 \\
\hline \multirow[t]{2}{*}{ Soybean } & Female & $3.9 \pm 0.8$ & $0.9 \pm 5.7$ & $134.1 \pm 7.5$ & $668.1 \pm 36.7$ & 10.2 & 0.95 \\
\hline & Male & $5.5 \pm 3.2$ & $1.7 \pm 12.0$ & $110.7 \pm 13.4$ & $690.0 \pm 77.4$ & 24.8 & 0.72 \\
\hline
\end{tabular}

a Abbreviations: GDD = growing degree days (base $10 \mathrm{C}$ ); RMSE = root mean square error; MEF = modeling efficiency. ${ }^{\mathrm{b}} \mathrm{Y}=c+(d-c) /\left(1+\left(x / \mathrm{GDD}_{50}\right)^{-b}\right)$, where $\mathrm{Y}=$ A. palmeri height, $c=$ the minimum height, $d=$ the maximum height, $\mathrm{GDD}_{50}=$ accumulated GDD since planting at which $50 \%$ of the maximum plant height was achieved, and $b=$ the slope of the regression line. ${ }^{c}$ Values are mean \pm standard error. ${ }^{\mathrm{d}}$ RMSE values closer to zero indicate predicted values are closer to the observed values. ${ }^{\mathrm{e}} \mathrm{MEF}$ closer to one suggests model predictions are more accurate.

The logistic models described the relationship of female (RMSE 2.1 to 11.5, MEF 0.95 to 0.99) and male (RMSE 9.9 to 24.8, MEF 0.56 to 0.96) A. palmeri heights in Cohort 2 and GDDs (Table 1). Crop canopies had a three-week advantage on Cohort 2, which may explain the reduction in goodness of fit of the model as A. palmeri growth was more variable. As with Cohort 1, only the crop influenced A. palmeri height over time $(p<0.0001, \mathrm{~F}=52.3$; Figure 2). The canopy of $A$. palmeri was tallest in cotton $(155 \mathrm{~cm})$ and peanut $(151 \mathrm{~cm})$, followed by that in soybean $(121 \mathrm{~cm})$ and in corn $(30 \mathrm{~cm})$. This indicates that the height of competing crop is not the only determinant of the final height of $A$. palmeri. Other physiological traits of the competing crop and the ability of the crop to compete with the weed below ground also modifies the final stature of A. palmeri. Corn and soybean have taller or denser canopies than peanut and cotton, thus differentially affecting the ability of A. palmeri to compete for sunlight. Emerging 3 WAP reduced A. palmeri final height in corn, cotton, peanut, and soybean $87,23,15$, and $32 \%$, respectively. Webster and Grey [12] and Norsworthy et al. [16] reported 11.5 and $24 \%$ decreases in A. palmeri height when emerging three weeks after cotton compared to emerging with the crop.

When the data for Cohort 1 and 2 were transformed into the percent of maximum height modeled against $\mathrm{GDD}_{10}$, the growth lines converge more tightly (Figure $3 \mathrm{~A}, \mathrm{~B}$ ). The GDDs needed to achieve 10, 50, and 90\% in Cohort 1 differed by crop $(p<0.0001$ to 0.0274 , $\mathrm{F}=3.8$ to 31.3), but were not influenced by the gender of $A$. palmeri nor the interaction of crop and gender $(p>0.1)$. Amaranthus palmeri in cotton $\left(387 \mathrm{GDD}_{10}\right)$ took longer to reach $10 \%$ of their maximum height compared to those growing with soybean $\left(359 \mathrm{GDD}_{10}\right)$ and corn (361 GDD 10 ; Figure 4). 

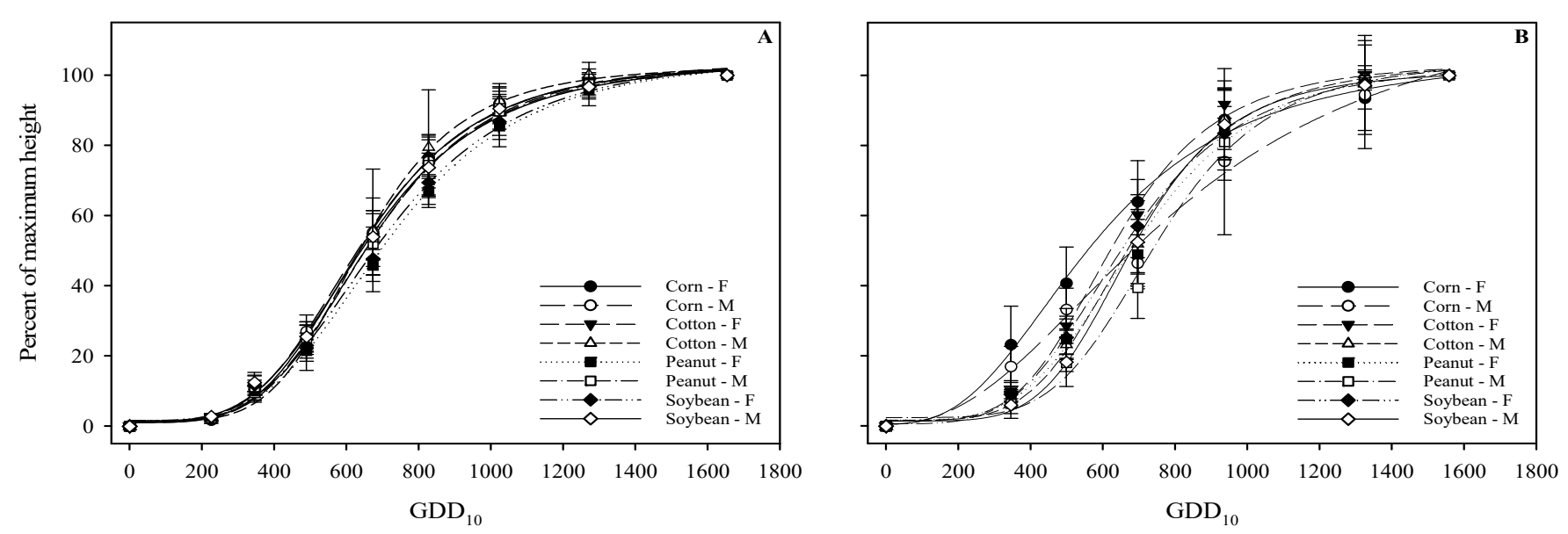

Figure 3. Male (M) and female (F) Palmer amaranth (Amaranthus palmeri) percent of maximum heights modeled against growing degree days (GDD; base $10 \mathrm{C}$ ) when competing with corn, cotton, peanut, and soybean crops. Amaranthus palmeri was allowed to emerge with the crops (Cohort 1); (A) and three weeks after crop planting (Cohort 2); (B). Growing degree day 0 represents crop planting (Cohort 1) or three weeks after crop planting (Cohort 2). Error bars represent $95 \%$ confidence intervals. Data are pooled over two field sites.

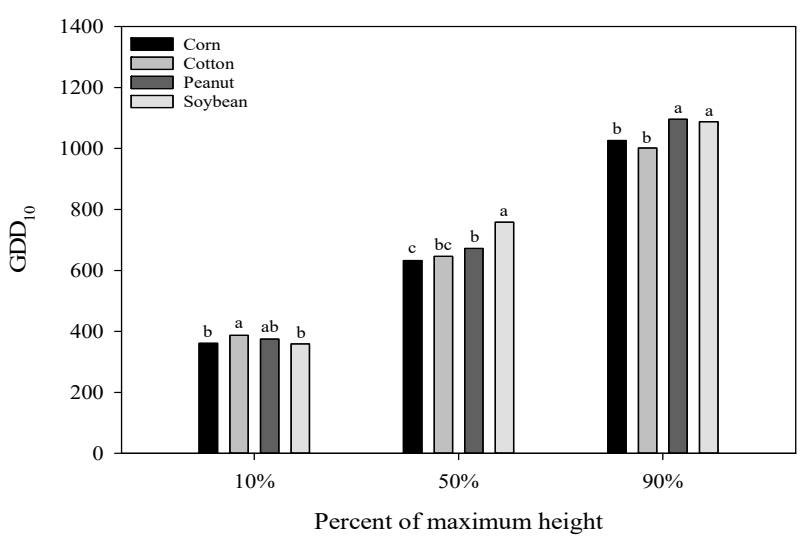

(A)

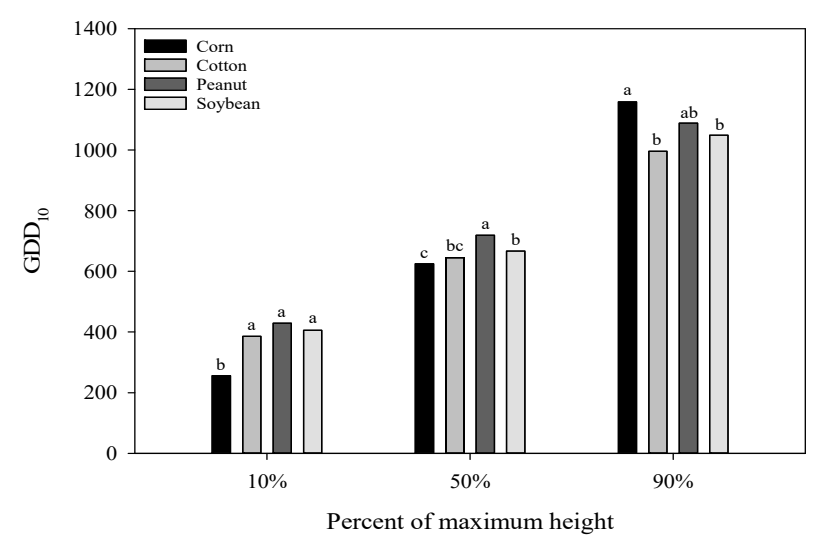

(B)

Figure 4. Growing degree days (GDD) required for Palmer amaranth (Amaranthus palmeri) to reach 10, 50, and 90\% of maximum height when competing with corn, cotton, peanut, and soybean crops. Cohort 1 (A) was allowed to emerge with the crop while Cohort 2 (B) emerged three weeks after planting. Data bars within percent of maximum height categories that have the same letter are not significantly different according to Fisher's protected LSD $(\alpha=0.05)$. Data are pooled over A. palmeri gender and two field sites.

Amaranthus palmeri in soybean $\left(758 \mathrm{GDD}_{10}\right)$ took the longest to reach $50 \%$ of maximum height compared to all other crops (633 to $672 \mathrm{GDD}_{10}$ ). Additionally, A. palmeri growing with peanut $\left(672 \mathrm{GDD}_{10}\right)$ grew slower than those with corn $\left(633 \mathrm{GDD}_{10}\right)$. When growing with corn and cotton, A. palmeri reached 90\% of their maximum height (1026 and 1002 $\mathrm{GDD}_{10}$, respectively) faster than when growing with peanut and soybean (1096 and 1088 $\mathrm{GDD}_{10}$, respectively). Similar to Cohort 1 , cropping system influenced the GDDs needed to reach certain growth percentages $(p<0.0001$ to $0.0287, \mathrm{~F}=3.8$ to 27.0) in Cohort 2. Thus, $A$. palmeri in corn $\left(256 \mathrm{GDD}_{10}\right)$ reached $10 \%$ of maximum height faster than those in the other crops (386 to $429 \mathrm{GDD}_{10}$; Figure 4). The plants of this weed growing in corn (625 GDD 10 ) achieved $50 \%$ of the maximum height quicker than in peanut $\left(719 \mathrm{GDD}_{10}\right)$ and soybean $\left(667 \mathrm{GDD}_{10}\right)$ but was similar to those in cotton. Peanut was the slowest environment to reach $50 \%$ of maximum $A$. palmeri height. However, in corn, plants took longer to reach $90 \%$ of maximum height than in cotton or soybean. This may be due to the corn canopy 
shedding lower leaves as the season progresses, which allowed more light penetration for A. palmeri to utilize.

With respect to Cohort 1 , the average and maximum growth rates for A. palmeri in corn ( 0.14 and $0.34 \mathrm{~cm} \mathrm{GDD} D_{10}$, respectively) and cotton $\left(0.13\right.$ and $\left.0.33 \mathrm{~cm} \mathrm{GDD} \mathrm{CD}_{10}\right)$ were greater than those measured in peanut ( 0.11 and $0.25 \mathrm{~cm} \mathrm{GDD} 10$, respectively) and soybean (0.11 and $0.25 \mathrm{~cm} \mathrm{GDD} 10$, respectively; Figure 5).
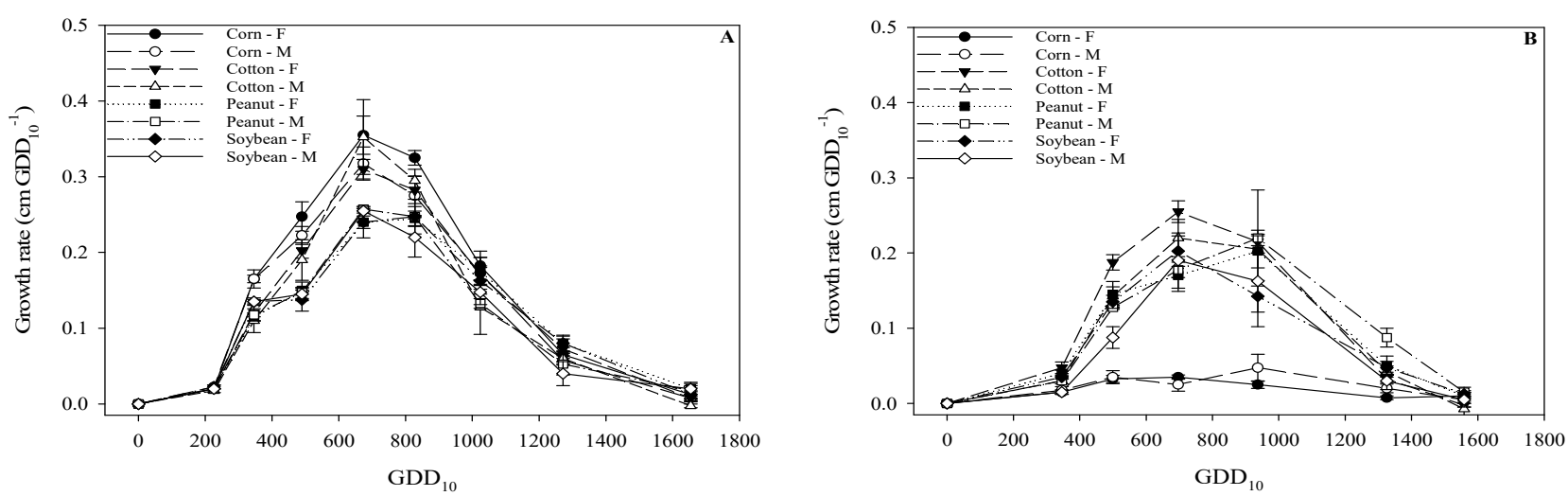

Figure 5. Male (M) and female (F) Palmer amaranth (Amaranthus palmeri) growth rates by growing degree day (GDD; base $10 \mathrm{C}$ ) when competing with corn, cotton, peanut, and soybean crops. Cohort 1 (A) emerged with the crop while Cohort 2 (B) emerged three weeks after crop planting. Error bars represent $95 \%$ confidence intervals. Data are pooled over two field sites.

Growth rates for Cohort 2 were less than that of Cohort 1 with average rates of $0.02,0.10,0.10$, and $0.08 \mathrm{~cm} \mathrm{GDD}_{10}{ }^{-1}$ in corn, cotton, peanut, and soybean, respectively (Figure 5). Maximum growth rates were also slower at $0.03,0.24,0.23$, and 0.20 , respectively. In Kansas, Horak and Loughin [14] observed growth rates of 0.18 and $0.21 \mathrm{~cm} \mathrm{GDD}^{-1}$ when mid-June-planted A. palmeri measured 100 and $87 \mathrm{~cm}$, respectively (approximately $50 \%$ of maximum height). Spaunhorst et al. [3] reported growth rates of 0.14 to $0.17 \mathrm{~cm}$ $\mathrm{GDD}^{-1}$ to $50 \%$ of maximum height. These are in good agreement with this research with growth rates of $0.18,0.16,0.13$, and $0.12 \mathrm{~cm} \mathrm{GDD}^{-1}$ for A. palmeri emerging with the crop (Cohort 1 ) to reach 50\% of maximum height in corn, cotton, peanut, and soybean, respectively (Figure 3 ).

In 2018, NC had approximately 404,685 ha, 145,687 ha, 43,706 ha, and 647,500 ha of corn, cotton, peanut, and soybean, respectively [27]. In soybean and peanut, contact herbicides such as fomesafen and acifluorfen are commonly used for A. palmeri control in soybean and peanut, respectively, while glufosinate is used in glufosinate-tolerant corn, cotton, and soybean. The manufacturer's product label of these herbicides recommend application at a maximum height of $10 \mathrm{~cm}$ for good control of A. palmeri. Amaranthus palmeri in Cohort 1 achieved $10 \mathrm{~cm}$ in 17 to $18 \mathrm{~d}$ in corn (i.e., 200 to $300 \mathrm{GDD}_{10}$ ), cotton, peanut, and soybean. This means herbicides need to be applied no later than $18 \mathrm{~d}$ from weed emergence. In Cohort 2, A. palmeri reached a height of $10 \mathrm{~cm}$ in 30, 19, 21, and $21 \mathrm{~d}$ (i.e., 350 to $375 \mathrm{GDD}_{10}$ ) after the 3 WAP mark in corn, cotton, peanut, and soybean, respectively. Thus, later-emerging A. palmeri still needs to be sprayed no later than $3 \mathrm{w}$ after emergence in these crops, except for corn. However, how late one can spray herbicides in corn is dictated by the layby growth stage timing of corn.

\subsection{Canopy Wdth of A. palmeri}

The logistic models described the relationship of Cohort 1 female (RMSE 2.1 to 24.8, MEF 0.83 to 0.96 ) and male (RMSE 4.2 to 8.6 , MEF 0.88 to 0.94 ) A. palmeri widths and GDDs (Table 2). 
Table 2. Parameter estimates and goodness of fit using the four-parameter logistic function to fit male and female Palmer amaranth (Amaranthus palmeri) width when emerging with (Cohort 1) corn, cotton, peanut, and soybean crops ${ }^{\mathrm{a}, \mathrm{b}}$.

\begin{tabular}{|c|c|c|c|c|c|c|c|}
\hline Crop & Gender & $B^{c}$ & $C^{\mathrm{c}}$ & $D^{c}$ & $\mathrm{GDD}_{50}$ & RMSE $^{\mathrm{d}}$ & MEF $^{\mathrm{e}}$ \\
\hline \multirow{3}{*}{ Corn } & & & & - & & & \\
\hline & Female & $3.9 \pm 1.7$ & $0.1 \pm 3.3$ & $41.1 \pm 2.1$ & $335.8 \pm 32.1$ & 5.8 & 0.83 \\
\hline & Male & $4.4 \pm 1.9$ & $0.1 \pm 2.4$ & $37.2 \pm 1.4$ & $314.7 \pm 26.6$ & 4.2 & 0.88 \\
\hline \multirow[t]{2}{*}{ Cotton } & Female & $3.0 \pm 0.4$ & $\begin{array}{c}-0.5 \pm \\
4.6\end{array}$ & $125.7 \pm 6.0$ & $564.9 \pm 31.3$ & 8.3 & 0.96 \\
\hline & Male & $3.9 \pm 0.7$ & $0.7 \pm 4.8$ & $96.4 \pm 4.0$ & $498.8 \pm 27.9$ & 8.6 & 0.93 \\
\hline Peanut & Female & $2.6 \pm 0.5$ & $\begin{array}{c}-0.1 \pm \\
5.3\end{array}$ & $110.3 \pm 9.2$ & $602.2 \pm 56.8$ & 9.4 & 0.92 \\
\hline \multirow{3}{*}{ Soybean } & Male & $3.3 \pm 0.5$ & $0.2 \pm 3.9$ & $89.1 \pm 4.0$ & $514.3 \pm 29.7$ & 7.0 & 0.94 \\
\hline & Female & $2.2 \pm 0.6$ & $0.1 \pm 3.8$ & $67.7 \pm 7.0$ & $512.9 \pm 67.3$ & 6.8 & 0.89 \\
\hline & Male & $3.6 \pm 0.8$ & $0.2 \pm 2.4$ & $46.6 \pm 1.7$ & $377.9 \pm 22.0$ & 4.2 & 0.92 \\
\hline
\end{tabular}

a Abbreviations: GDD = growing degree days (base $10 \mathrm{C}$ ); RMSE = root mean square error; MEF = modeling efficiency. ${ }^{\mathrm{b}} \mathrm{Y}=c+(d-c) /\left(1+\left(x / \mathrm{GDD}_{50}\right)^{-b}\right)$, where $\mathrm{Y}=$ A. palmeri height, $c=$ the minimum height, $d=$ the maximum height, $\mathrm{GDD}_{50}=$ accumulated GDD since planting at which $50 \%$ of the maximum plant height was achieved, and $b=$ the slope of the regression line. ${ }^{c}$ Values are mean \pm standard error. ${ }^{\mathrm{d}}$ RMSE values closer to zero indicate that predicted values are closer to the observed values. ${ }^{\mathrm{e}} \mathrm{MEF}$ closer to one suggests model predictions are more accurate.

Generally, differences in the A. palmeri canopy width were evident across cropping systems (Figure 6). Female plants had wider canopies (more branching and leaf area) than male plants. The main effects of crop $(p<0.0001, \mathrm{~F}=91.6)$ and gender $(p<0.0001$, $\mathrm{F}=25.6$ ) on the final canopy width of $A$. palmeri were significant, but the interaction of the two was not $(p=0.1511)$. The canopy width of Amaranthus palmeri in competition with cotton $(105.0 \mathrm{~cm})$ and peanut $(95.2 \mathrm{~cm})$ was largest, followed by soybean $(54.5 \mathrm{~cm})$ and corn $(38.4 \mathrm{~cm})$. Averaged over cropping systems, female plants had a greater canopy width $(81 \mathrm{~cm})$ than male plants $(67 \mathrm{~cm})$. In sweet potato, Ipomoea batatas (L.) Lam., Meyers et al. [5] reported that the widths of $A$. palmeri Palmer decreased from 145 to $69 \mathrm{~cm}$ as weed density increased. Webster and Grey [12] also studied canopy development by gender and found that female A. palmeri plants have a wider canopy $(126 \mathrm{~cm})$ than the males $(93 \mathrm{~cm})$. Our study supports this. Canopy width in Cohort 2 was less than in Cohort 1 (Figure 6B). The canopy expansion of Cohort 2 followed a quadratic model with GDD for males at RMSE 2.6 to 5.7 and MEF of 0.53 to 0.90 (Table 3).

Table 3. Parameter estimates and goodness of fit using the quadratic function $\left(Y=y 0+a * x+b * x^{2}\right)$ to fit male and female Palmer amaranth (Amaranthus palmeri) width when emerging three weeks after (Cohort 2) corn, cotton, peanut, and soybean crops ${ }^{\mathrm{a}}$.

\begin{tabular}{|c|c|c|c|c|c|c|}
\hline Crop & Gender & $y 0^{b}$ & $a^{\mathrm{b}}$ & $B^{b}$ & RMSE $^{c}$ & $\mathrm{MEF}^{\mathrm{d}}$ \\
\hline \multirow{3}{*}{ Corn } & & & $\mathrm{Cn}$ & & & \\
\hline & Female & $-0.28 \pm 0.990$ & $0.03 \pm 0.002$ & $-1.45 \times 10^{-5} \pm 1.71 \times 10^{-6}$ & 1.8 & 0.76 \\
\hline & Male & $-0.02 \pm 1.432$ & $0.02 \pm 0.004$ & $-1.25 \times 10^{-5} \pm 2.48 \times 10^{-6}$ & 2.6 & 0.53 \\
\hline \multirow[t]{2}{*}{ Cotton } & Female & $-1.77 \pm 3.171$ & $0.08 \pm 0.009$ & $-4.23 \times 10^{-5} \pm 5.49 \times 10^{-6}$ & 5.8 & 0.78 \\
\hline & Male & $-1.77 \pm 1.799$ & $0.07 \pm 0.005$ & $-3.70 \times 10^{-5} \pm 3.1 \times 10^{-6}$ & 3.3 & 0.86 \\
\hline \multirow[t]{2}{*}{ Peanut } & Female & $-1.97 \pm 4.119$ & $0.07 \pm 0.012$ & $-2.70 \times 10^{-5} \pm 7.13 \times 10^{-6}$ & 7.5 & 0.71 \\
\hline & Male & $-3.40 \pm 4.278$ & $0.08 \pm 0.012$ & $-3.45 \times 10^{-5} \pm 7.41 \times 10^{-6}$ & 5.7 & 0.90 \\
\hline \multirow[t]{2}{*}{ Soybean } & Female & $-0.12 \pm 1.933$ & $0.05 \pm 0.006$ & $-2.62 \times 10^{-5} \pm 3.35 \times 10^{-6}$ & 3.5 & 0.79 \\
\hline & Male & $-2.29 \pm 2.790$ & $0.05 \pm 0.008$ & $-2.76 \times 10^{-5} \pm 4.83 \times 10^{-6}$ & 5.1 & 0.61 \\
\hline
\end{tabular}

a Abbreviations: GDD = growing degree days (base $10 \mathrm{C}$ ); RMSE = root mean square error; MEF = modeling efficiency. ${ }^{b}$ Values are mean \pm standard error. ${ }^{c}$ RMSE values closer to zero indicate predicted values are closer to the observed values. ${ }^{d}$ MEF closer to one suggests model predictions are more accurate. 


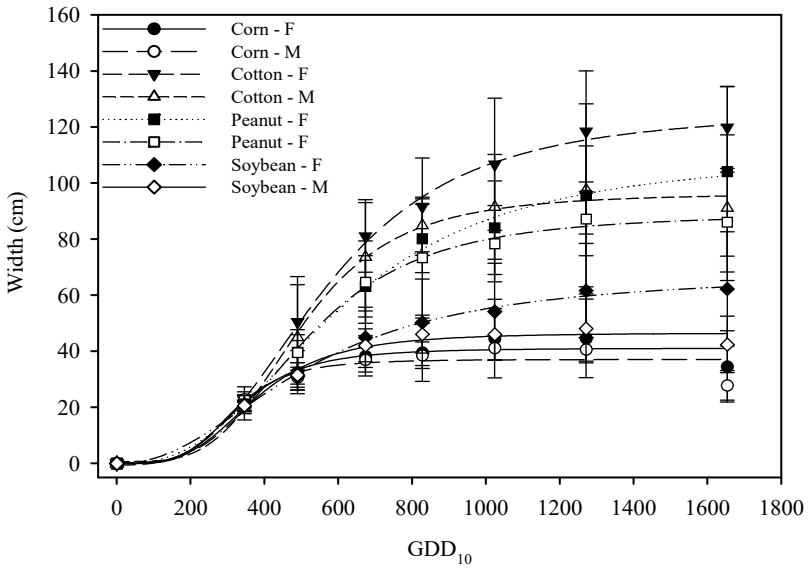

(A)

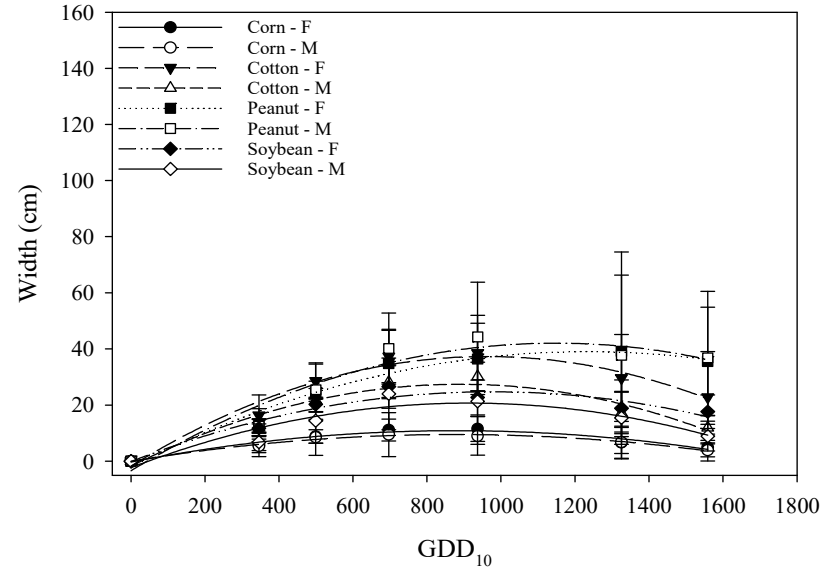

(B)

Figure 6. Male (M) and female (F) Palmer amaranth (Amaranthus palmeri) widths modeled against growing degree days (GDD; base $10 \mathrm{C}$ ) when competing with corn, cotton, peanut, and soybean crops. Amaranthus palmeri was allowed to emerge with the crops (Cohort $1 ;(\mathbf{A})$ ) and three weeks after crop planting (Cohort 2; (B)). Parameter estimates for Cohort 1 and Cohort 2 can be found in Tables 1 and 2, respectively. Growing degree day 0 represents crop planting (Cohort 1$)$ or three weeks after crop planting (Cohort 2). Error bars represent 95\% confidence intervals. Data are pooled over two field sites.

The RMSE for females ranged from 1.8 to 7.5 with MEF values of 0.71 to 0.78 ). As the season progressed, A. palmeri leaves began to senesce, producing a growth curve that best fits a quadratic model. These data suggest that gender did not influence canopy width throughout the season for Cohort 2 , nor the final width $(p=0.0564)$. The cropping system did affect canopy width $(p<0.0001, \mathrm{~F}=23.7)$ as A. palmeri competing with peanut had a wider canopy $(36.5 \mathrm{~cm})$ than those competing with soybean $(15.6 \mathrm{~cm})$, cotton $(18.5 \mathrm{~cm})$, and corn $(3.5 \mathrm{~cm})$. The canopy structure of A. palmeri mimicked the canopy structure of the crop, becoming narrower when growing with corn. This reflected canopy modifications to better compete for light in a narrow inter-row of tall-canopy corn. Webster and Grey [12] reported A. palmeri emerging three weeks after cotton had final widths of 45 and $78 \mathrm{~cm}$ for male and female plants, respectively.

\subsection{A. palmeri Soot Bomass}

For A. palmeri plants in Cohort 1, the interaction of cropping system and gender $(p=0.0002, \mathrm{~F}=6.7)$ influenced plant biomass at harvest. Female plants in cotton $(2014 \mathrm{~g}$ plant $^{-1}$ ) and peanut (1879 $\mathrm{g} \mathrm{plant}^{-1}$ ) were larger than plants in any other cropping system (Figure 7). This could be explained by the cotton canopy being open and row width being wide, resulting in less competition for light. Similarly, light competition with peanut would be minimal because peanut is low-growing, allowing $A$. palmeri to grow above this crop quickly. Male $A$. palmeri in cotton $\left(934 \mathrm{~g} \mathrm{plant}^{-1}\right)$ and peanut $\left(879 \mathrm{~g} \mathrm{plant}^{-1}\right)$ were similar and larger than male or female plants in both corn (77 and $195 \mathrm{~g} \mathrm{plant}^{-1}$, respectively) and soybean (258 and $434 \mathrm{~g} \mathrm{plant}^{-1}$, respectively). Within each cropping system, female plants had 68 to $153 \%$ more biomass than their male counterparts. Thus, female plants are always larger than male plants. This conclusion is consistent with the data of Webster and Grey [12], wherein females were 167\% larger than males when competing with cotton season long. 


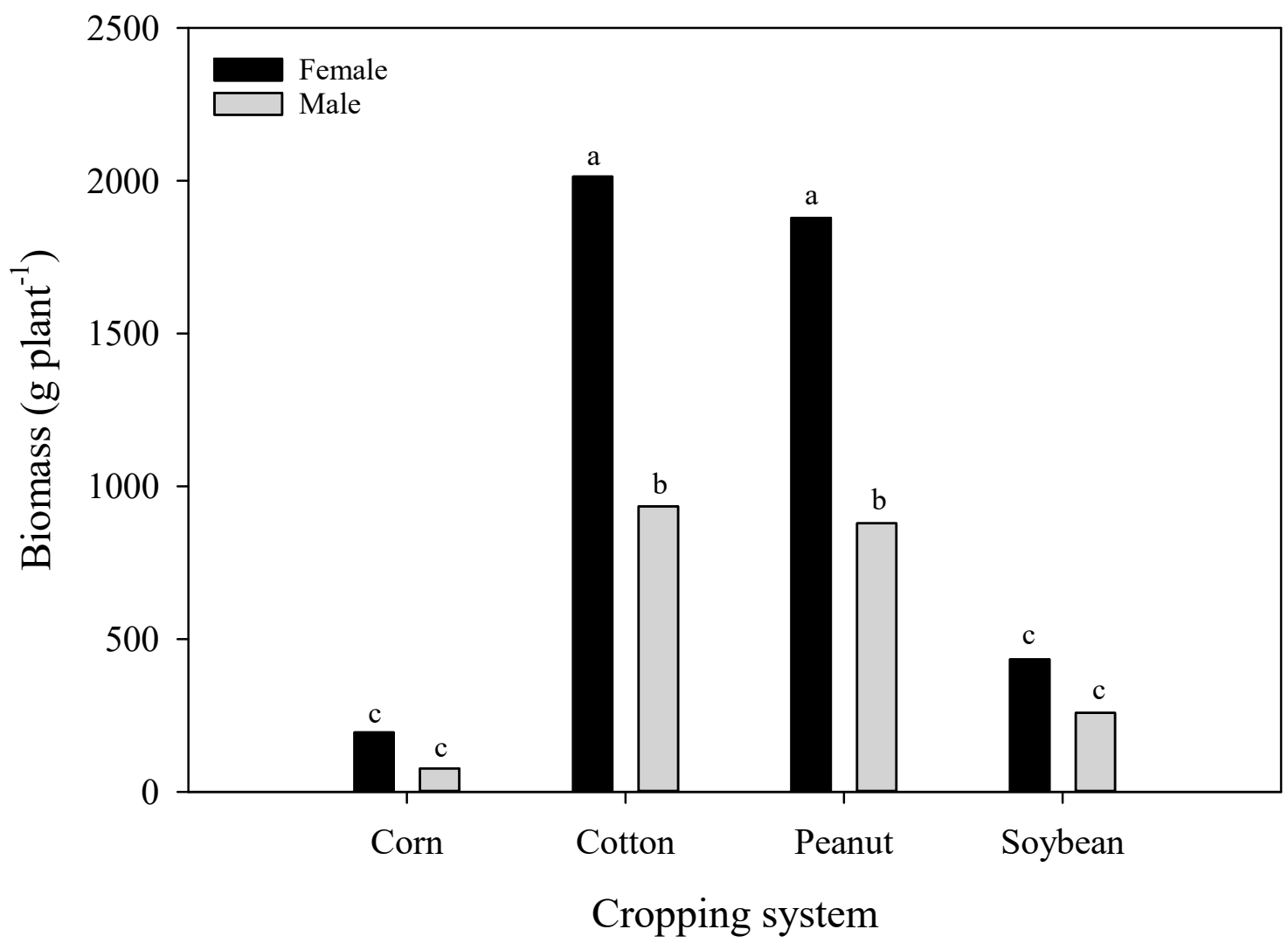

Figure 7. Fresh biomass of male and female Palmer amaranth (Amaranthus palmeri) from Cohort 1 at harvest (14 w after crop planting). Plants were allowed to emerge and compete season long with corn, cotton, peanut, and soybean. Data bars with the same letter are not significantly different according to Fisher's protected LSD $(\alpha=0.05)$. Data are pooled over two field sites.

The final biomass for A. palmeri emerging 3 WAP (Cohort 2) was affected only by cropping system $(p<0.0001, \mathrm{~F}=11.5)$, but not by gender $(p=0.2020)$. The interaction of these factors was also not significant $(p=0.1629)$. Cohort 2 of $A$. palmeri in peanut had the largest fresh biomass (166 g plant ${ }^{-1}$ ) compared to all other crops (Figure 8). A. palmeri in cotton $\left(83 \mathrm{~g} \mathrm{plant}^{-1}\right)$ and soybean $\left(35 \mathrm{~g} \mathrm{plant}^{-1}\right)$ were similar with those in cotton being larger than those in corn $\left(2 \mathrm{~g} \mathrm{plant}^{-1}\right)$. When comparing Cohort 1 and Cohort 2 biomass, the biomass for the latter was 85 to $99 \%$ less than the former, across cropping systems. In Arkansas, Norsworthy et al. [16] reported a $64 \%$ reduction in female A. palmeri biomass when it emerged three weeks after cotton compared to those emerging with the crop. In Georgia, A. palmeri biomass was about $80 \%$ less, across genders, when emerging 3 weeks after cotton as opposed to with the crop [12]. Therefore, applying PRE herbicides is critical in controlling the first flush of $A$. palmeri, giving the crop a high competitive advantage. More importantly, A. palmeri biomass is highly correlated with seed production. 


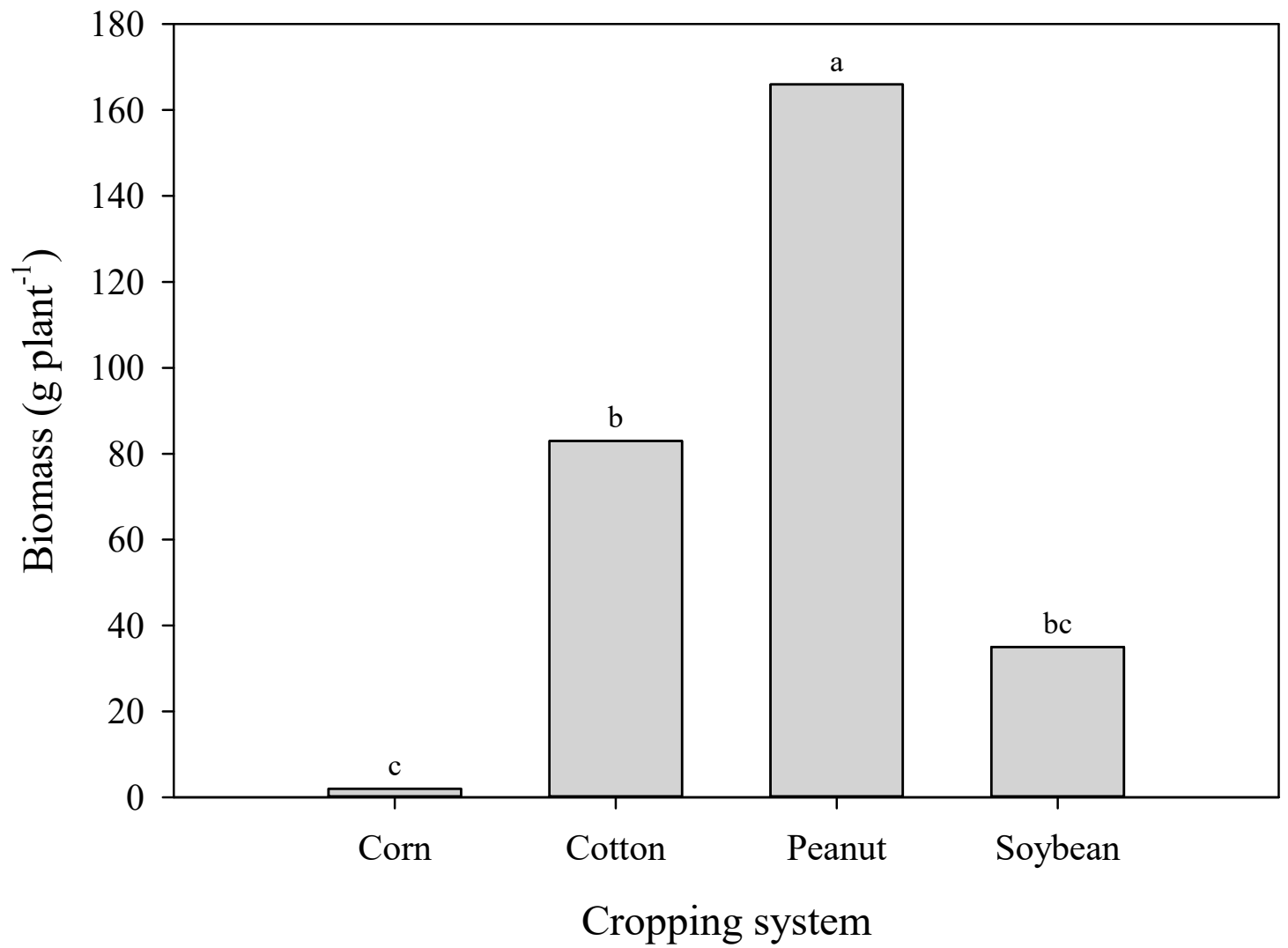

Figure 8. Fresh biomass of Palmer amaranth (Amaranthus palmeri) from Cohort 2 at harvest (17 w after crop planting). Plants were allowed to emerge $3 \mathrm{w}$ after crop planting and compete season long with corn, cotton, peanut, and soybean. Data bars with the same letter are not significantly different according to Fisher's protected LSD $(\alpha=0.05)$. Data are pooled over plant gender and two field sites.

\subsection{Seed Poduction of A. palmeri in Cop Cmpetition}

Seed production for Cohort 1 was not correlated with plant height $(r=0.03)$ but was correlated with canopy width $(r=0.71)$ and plant biomass $(r=0.63)$ suggesting that as width or biomass increases, so does seed production (Figure 9). Spaunhorst et al. [3] reported similar biomass and seed correlations $(\mathrm{r}=0.63)$ from $A$. palmeri populations grown in Arkansas. Schwartz et al. [28] described good correlations of biomass and seed production in A. palmeri $(\mathrm{r}=0.79)$ and tall water hemp [Amaranthus tuberculatus (Monq.) Sauer; $\mathrm{r}=0.73$ ] across multiple states. In Georgia, Webster and Grey [12] also determined a strong relationship $(\mathrm{r}=0.81)$ between $A$. palmeri biomass and total seed production. The cropping system influenced total seed production $(p<0.0001, \mathrm{~F}=48.9)$ with average seed production in cotton $\left(534,442\right.$ seeds plant $\left.{ }^{-1}\right)$ and peanut $\left(443,228\right.$ seeds plant $\left.{ }^{-1}\right)$ being similar and greater than seed production in soybean $\left(173,093\right.$ seeds plant $^{-1}$; Figure 10). Amaranthus palmeri in competition with corn $\left(51,024\right.$ seeds plant $\left.^{-1}\right)$ averaged the lowest seed production. 

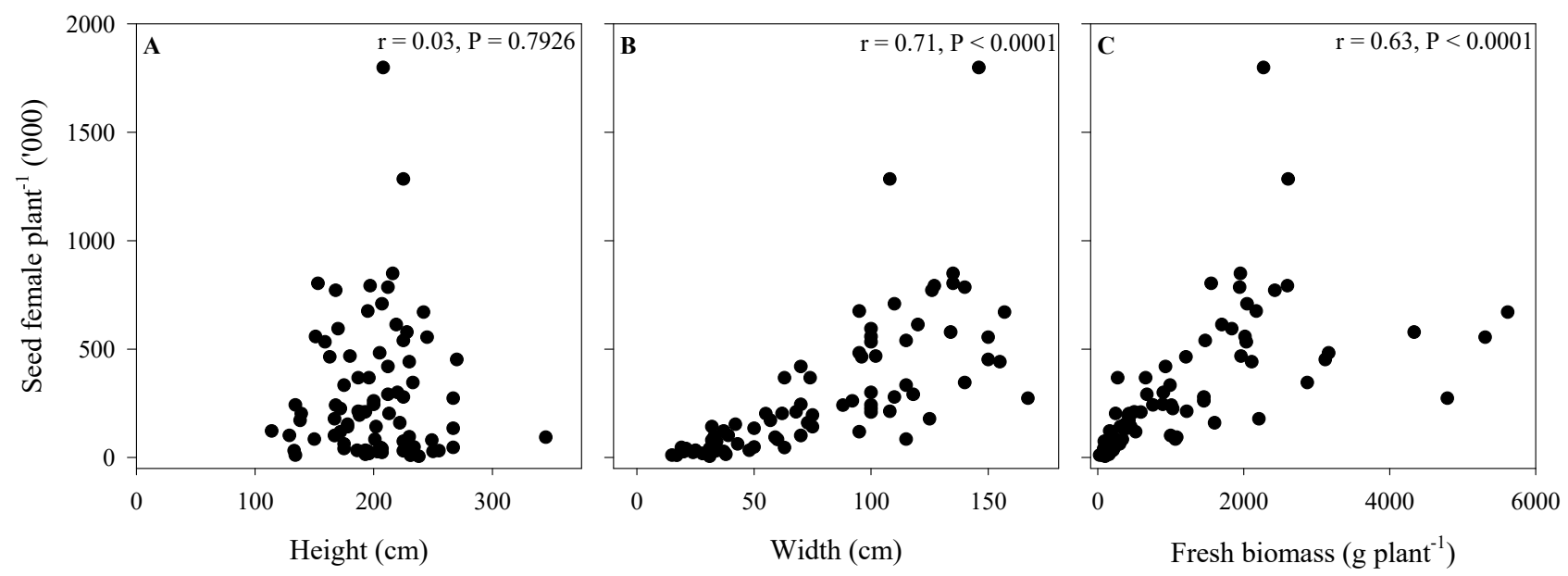

Figure 9. Correlations between final height (A), width (B), or fresh biomass $(\mathbf{C})$ and total seed production $(\mathrm{n}=80)$ of Palmer amaranth (Amaranthus palmeri) from Cohort 1. Plants were allowed to emerge and compete season long against corn, cotton, peanut, and soybean. Data are pooled over two field sites and four cropping systems.

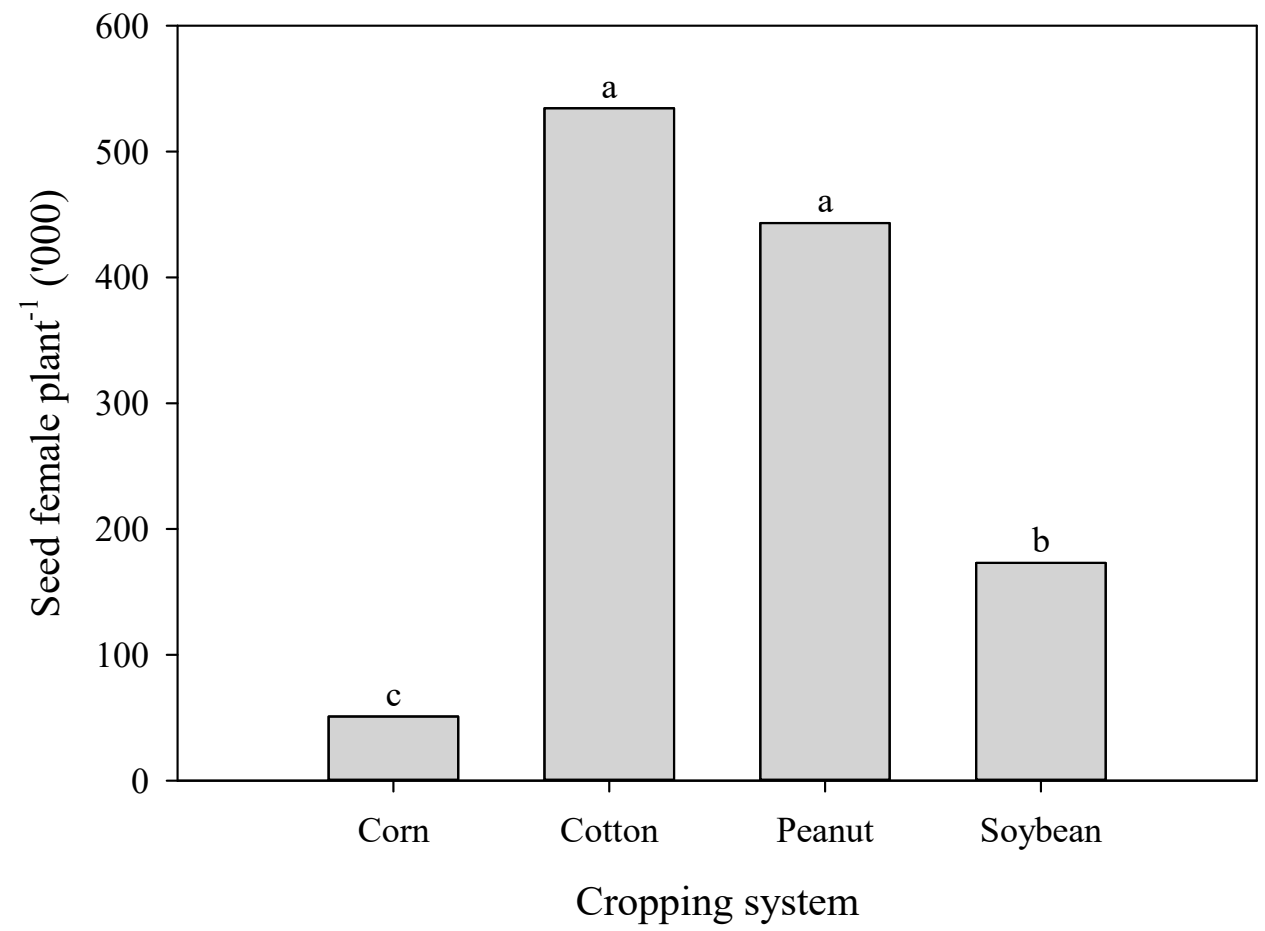

Figure 10. Seed production of female Palmer amaranth (Amaranthus palmeri) from Cohort 1 when competing with corn, cotton, peanut, and soybean crops. Plants were allowed to emerge and compete season long. Data bars with the same letter are not different according to Fisher's protected LSD at $\alpha=0.05$. Data are pooled over two field sites.

In California, Keeley et al. [2] reported a reproduction of upwards of 613,000 seed plant $^{-1}$ when $A$. palmeri was grown without competition. When competing with cotton season long in Georgia, Webster and Grey [12] and Sosnoskie et al. [25] reported average seed production of 312,000 and 435,000 seeds plant ${ }^{-1}$, respectively. In soybean, Bensch et al. [29] reported that $A$. palmeri produced approximately 100,000 to 200,000 seeds $\mathrm{m}^{-2}$ when emerging with the crop and competing season long. This production is approximately one-quarter to one-half of the seed production in our study (Figure 11). 

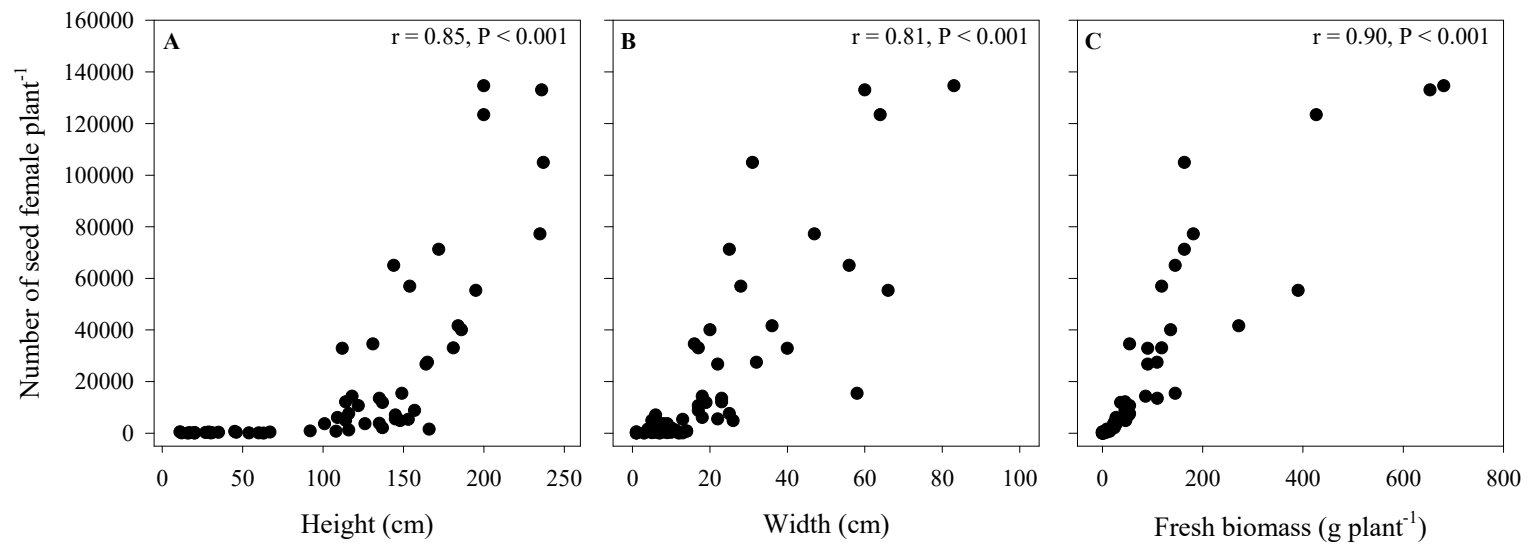

Figure 11. Correlations between final height (A), width (B), or fresh biomass (C) and total seed production $(n=56)$ of Palmer amaranth (Amaranthus palmeri) from Cohort 2. Plants were allowed to emerge three weeks after the crop and compete season long against corn, cotton, peanut, and soybean. Data are pooled over two field sites and four cropping systems.

However, this may be explained by the biomass of plants in the Bensch et al. [29] study, which was reduced to similar proportions when compared to plants in our study. As discussed, seed production is correlated to plant biomass (Figure 8). In Kansas, Massinga et al. [30] reported A. palmeri produced 140,000 $\mathrm{m}^{-2}$ when competing with corn season long. While greater than what was observed in our study (approximately 102,000 seed $\mathrm{m}^{-2}$ ), these data illustrate the vast amount of seed that one plant can contribute to the soil seedbank if left to compete season long (Figure 10).

Seed production from A. palmeri in Cohort 2 was correlated with plant height $(\mathrm{r}=0.85)$, width $(r=0.81)$, and biomass $(r=0.90$; Figure 10$)$. The cropping system influenced seed production $(p<0.0001 ; \mathrm{F}=47.3)$ with trends being similar to Cohort 1 . Amaranthus palmeri emerging three WAP cotton $\left(38,531\right.$ seed plant $\left.^{-1}\right)$ and peanut $\left(36,211\right.$ seed plant $\left.{ }^{-1}\right)$ produced similar amounts of seed with both being greater than A. palmeri in soybean (3742 seed plant $^{-1}$; Figure 12).

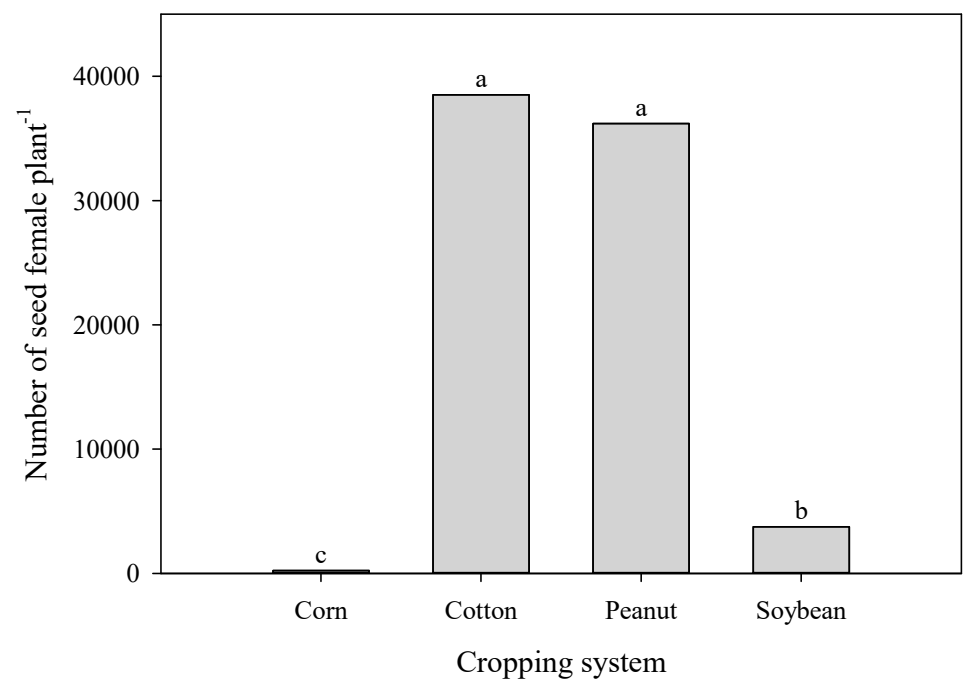

Figure 12. Seed production of female Palmer amaranth (Amaranthus palmeri) from Cohort 2 when competing with corn, cotton, peanut, and soybean crops. Plants were allowed to emerge three weeks after the crop and compete season long. Data bars with the same letter are not different according to Fisher's protected LSD at $\alpha=0.05$. Data are pooled over two field sites.

Corn produced the lowest amount, averaging only 224 seed plant ${ }^{-1}$. Reductions in A. palmeri seed production when it emerges after the crop has previously been observed. Webster and Grey [12] reported A. palmeri emerging three WAP cotton was able to produce 
approximately 76,000 seed plant $^{-1}$ (76\% reduction), while Norsworthy et al. [16] observed approximately 51,000 seed plant $^{-1}$ (30\% reduction). When emerging 3 to 4 weeks after corn, Massinga et al. [30] measured approximately 1800 seeds $\mathrm{m}^{-2}$ were produced, a $99 \%$ reduction when compared to $A$. palmeri that emerged with corn and competed season long. The presented data support previous research showing the vast reduction is seed production (greater than $90 \%$ reduction) when $A$. palmeri emerges weeks after the crop. This illustrates the importance of a residual herbicide applied at planting to control the initial flush of A. palmeri to give the crop a competitive advantage. The data also demonstrate the importance of controlling escaped A. palmeri even when it emerges weeks after the crop, as it still has the capacity to produce thousands of seeds and the advantage of more competitive crop canopies.

\section{Summary and Conclusions}

Amaranthus palmeri is a highly competitive weed that can cause short- and long-term problems for farm managers. In the short term, timely herbicide applications are needed to control this weed if a residual herbicide was not applied. Amaranthus palmeri was $10 \mathrm{~cm}$ in height approximately 17 to $18 \mathrm{~d}$ after it emerged with corn, cotton, peanut, or soybean. It is imperative to be timely with applications to ensure that adequate control of emerged A. palmeri is achieved, and it is recommended to include a residual herbicide with postemergence herbicides for extended control. The rate of growth beyond this point exceeded $5 \mathrm{~cm} \mathrm{~d}^{-1}$ creating enormous light competition with the crop. If a PRE herbicide was applied and adequate control was received, farm managers must still be cognizant of their timelines. Amaranthus palmeri, which emerges three weeks after cotton, peanut, or soybean, reached $10 \mathrm{~cm}$ in height approximately three weeks after emergence. In corn, this height was achieved in approximately four weeks. Robust growth may still occur with a later cohort as growth rates of greater than four $\mathrm{cm} \mathrm{d}^{-1}$ were measured.

Long term, farm managers must consider the weed seedbank. Amaranthus palmeri produced approximately $51,000,534,000,434,000$, and 173,000 seed plant ${ }^{-1}$ in corn, cotton, peanut, and soybean, respectively. While it is not likely that farm managers would allow A. palmeri to emerge with the crop and compete season long, later emerging cohorts still require much attention. Cotton and peanut were the least competitive, and A. palmeri was still able to produce greater than 35,000 seed plant ${ }^{-1}$. Less seed was produced in soybean (3000 seed plant ${ }^{-1}$ ) and corn (200 seed plant $\left.{ }^{-1}\right)$. Good growing conditions in our study allowed for uniform crop stands, which may not always occur. A. palmeri may produce more biomass and seed if a non-uniform stand allows for more light interception. Additionally, A. palmeri emerging further away from the crop may respond differently in terms of competition with crops compared to our results. Nonetheless, these data illustrate why rotating corn is an important feature into an integrated weed management plan, as it provides a competitive advantage and alternative herbicide options. A. palmeri has shown the ability to morphologically adapt to differing cropping systems [31]; thus, multiple shorter canopied cropping systems followed by one taller in nature may provide the greatest benefit (i.e., peanut to sweetpotato, to soybean to corn). Further research is needed to better determine crop sequence effects and how they best fit into an integrated weed management plan. Results from this experiment are from a single growing cycle in two different fields with variation in previous cropping cycles and management practices. Additional research in different geographies and environmental conditions would strengthen the understanding of the production of seed for this species when A. palmeri is growing with these crops.

Producers must be timely and attentive when cotton follows peanut, or vice-versa, as these were the two least competitive crops against $A$. palmeri. Ultimately, a zero tolerance for escapes is required with this weed to minimize additions to the weed seedbank. With respect to herbicide-resistance mitigation, the problem can quickly become field-wide if one plant is allowed to escape and reproduce [32]. Additionally, the chances of selecting a 
herbicide-resistant individual increases as the population exposed to herbicides increases; thus, the decreasing additions to the seedbank reduce the amount of plants exposed.

Author Contributions: Conceptualization, D.J.M. and D.L.J.; methodology, D.J.M. and D.L.J.; statistical analysis, D.J.M.; investigation, D.J.M. and A.T.H.; resources, D.L.J.; data curation, D.L.J.; writing-original draft preparation, D.J.M. and D.L.J.; writing—review and editing, D.J.M., D.L.J., R.G.L., N.R.-B., M.C.V., K.M.J., W.J.E. and C.W.C.; project administration, D.L.J.; funding acquisition, D.L.J. All authors have read and agreed to the published version of the manuscript.

Funding: This research was supported financially by the North Carolina Agricultural Foundation and the North Carolina Peanut Growers Association, Inc.

Institutional Review Board Statement: Not applicable.

Informed Consent Statement: Not applicable.

Data Availability Statement: For data inquiry, please contact the corresponding author.

Acknowledgments: Appreciation is expressed to staff at the Upper Coastal Plain Research Station for technical assistance.

Conflicts of Interest: The authors declare no conflict of interest. The funders had no role in the design of the study; in the collection, analyses, or interpretation of data; in the writing of the manuscript, or in the decision to publish the results.

\section{References}

1. Van Wychen, L. WSSA Survey Ranks Palmer Amaranth as the Most Troublesome Weed in the US, Galium as the Most Troublesome in Canada. Weed Science Society of America. 2016. Available online: http://wssa.net/2016/04/wssa-survey-ranks-palmeramaranth-as-the-most-troublesome-weed-in-the-u-s-galium-as-the-most-troublesome-in-canada/ (accessed on 12 December 2019).

2. Keeley, P.E.; Carter, C.H.; Thullen, R.J. Influence of planting date on growth of Palmer amaranth (Amaranthus palmeri). Weed Sci. 1987, 35, 199-204. [CrossRef]

3. Spaunhorst, D.J.; Devkota, P.; Johnson, W.G.; Smeda, R.J.; Meyer, C.J.; Norsworthy, J.K. Phenology of five Palmer amaranth (Amaranthus palmeri) populations grown in northern Indiana and Arkansas. Weed Sci. 2018, 66, 457-469. [CrossRef]

4. Knight, A.M.; Everman, W.J.; Jordan, D.L.; Heiniger, R.W.; Smyth, T.J. Interactions of nitrogen source and rate and weed removal timing relative to nitrogen content in corn and weeds and corn grain yield. Int. Sch. Res. Not. 2017. [CrossRef] [PubMed]

5. Meyers, S.L.; Jennings, K.M.; Schultheis, J.R.; Monks, D.W. Interference of Palmer amaranth (Amaranthus palmeri) in sweetpotato. Weed Sci. 2010, 58, 199-203. [CrossRef]

6. Berger, S.T.; Ferrell, J.A.; Rowland, D.L.; Webster, T.W. Palmer amaranth (Amaranthus palmeri) competition for water in cotton. Weed Sci. 2015, 63, 928-935. [CrossRef]

7. Chandi, A.; Milla-Lewis, S.R.; Jordan, D.L.; York, A.C.; Burton, J.D.; Zuleta, M.C.; Whitaker, J.R.; Culpepper, A.S. Use of AFLP markers to assess genetic diversity in Palmer amaranth (Amaranthus palmeri) populations from North Carolina and Georgia. Weed Sci. 2013, 61, 136-145. [CrossRef]

8. Sosnoskie, L.M.; Webster, T.M.; Kichler, J.M.; MacRae, A.W.; Grey, T.L.; Culpepper, A.S. Pollen mediated dispersal of glyphosateresistance in Palmer amaranth under field conditions. Weed Sci. 2012, 60, 366-373. [CrossRef]

9. Heap, I. The International Survey of Herbicide Resistant Weeds. 2021. Available online: www.weedscience.org (accessed on 12 December 2019).

10. Ward, S.M.; Webster, T.M.; Steckel, L.E. Palmer amaranth (Amaranthus palmeri): A review. Weed Technol. 2013, 27, 12-27. [CrossRef]

11. Burke, I.C.; Schroeder, M.; Thomas, W.E.; Wilcut, J.W. Palmer amaranth interference and seed production in peanut. Weed Technol. 2007, 21, 367-371. [CrossRef]

12. Webster, T.M.; Grey, T.L. Glyphosate-resistant Palmer amaranth (Amaranthus palmeri) morphology, growth, and seed production in Georgia. Weed Sci. 2015, 63, 264-272. [CrossRef]

13. Bagavathiannan, M.V.; Davis, A.S. An ecological perspective on managing weeds during the great selection for herbicide resistance. Pest. Manag. Sci. 2018, 74, 2277-2286. [CrossRef]

14. Horak, M.J.; Loughin, T.M. Growth analysis of four Amaranthus species. Weed Sci. 2000, 48, 347-355. [CrossRef]

15. Sellers, B.A.; Smeda, R.J.; Johnson, W.G.; Kendig, J.A.; Ellersieck, M.R. Comparative growth of six Amaranthus species in Missouri. Weed Sci. 2003, 51, 329-333. [CrossRef]

16. Norsworthy, J.K.; Schrage, B.W.; Barber, T.L.; Schwartz, L.M. Emergence date influences growth and fecundity of Palmer amaranth in cotton. J. Cotton Sci. 2016, 20, 263-270.

17. Van Wychen, L. Scientists Advocate a Community-Based Approach to Herbicide Resistance Management. Weed Science Society of America. 2015. Available online: http:/ / wssa.net/2015/06/scientists-advocate-a-community-based-approach-to-herbicideresistance-management/ (accessed on 12 December 2019). 
18. Poirier, A.H.; York, A.C.; Jordan, D.L.; Chandi, A.; Everman, W.J.; Whitaker, J.R. Distribution of glyphosate- and thifensulfuronresistant Palmer amaranth (Amaranthus palmeri) in North Carolina. Int. J. Agron. 2014. [CrossRef]

19. Inman, M.D.; Jordan, D.L.; York, A.C.; Jennings, K.M.; Monks, D.W.; Everman, W.J.; Bollman, S.T.; Fowler, J.T.; Cole, R.M.; Soteres, J.K. Long-term management of Palmer amaranth in dicamba-tolerant cotton. Weed Sci. 2016, 64, 161-169. [CrossRef]

20. Isleib, T.G.; Milla-Lewis, S.R.; Pattee, H.E.; Copeland, S.C.; Zuleta, M.C.; Shew, B.B.; Hollowell, J.E.; Sanders, T.H.; Dean, L.O.; Hendrix, K.W.; et al. Registration of 'Bailey' peanut. J. Plant. Regist. 2011, 5, 27-39. [CrossRef]

21. Edmisten, K.; Collins, G.; Crozier, C.; York, A.; Hardy, D.; Reisig, D.; Bullen, G.; Thiessen, L.; Vann, R.; Cahoon, C.; et al. North Carolina Cotton Production Guide; North Carolina Cooperative Extension Service Pub AG-417: Raleigh, NC, USA, 2019.

22. Heiniger, R.; Spears, J.; Bowman, D.; Carson, M.L.; Crozier, C.; Dunphy, J.; Koenning, S.; Marra, M.; Naderman, G.C.; Van Duyn, J.; et al. Corn Production Guide; North Carolina Cooperative Extension Service Pub AG-590: Raleigh, NC, USA, 2019.

23. Jordan, D.L.; Brandenburg, R.; Brown, B.; Bullen, G.; Roberson, G.; Shew, B. 2019 Peanut Information; North Carolina Cooperative Extension Service Pub. AG-331: Raleigh, NC, USA, 2019.

24. Stowe, K.D.; Crozier, C.; Bullen, G.; Dunphy, E.J.; Everman, W.; Hardy, D.; Osmond, D.; Piggot, N.; Randa, S.; Reisig, D.; et al. North Carolina Soybean Production Guide; North Carolina Cooperative Extension Service Pub AG-835: Raleigh, NC, USA, 2017.

25. Sosnoskie, L.M.; Webster, T.M.; Grey, T.L.; Culpepper, A.S. Severed stems of Amaranthus palmeri are capable of regrowth and seed production in Gossypium hirsutum. Ann. Appl. Biol. 2014, 165, 147-154. [CrossRef]

26. Archontoulis, S.V.; Miguez, F.E. Nonlinear regression models and applications in agricultural research. Agron. J. 2015, 107, 786-798. [CrossRef]

27. USDA-NASS. 2020 State Agriculture Overview-North Carolina: Crops—Planted, Harvested, Yield, Production, Price (MYA), Value of Production. Available online: https:/ /www.nass.usda.gov/Quick_Stats/Ag_Overview/ (accessed on 20 May 2021).

28. Schwartz, L.M.; Norsworthy, J.K.; Young, B.G.; Bradley, K.W.; Kruger, G.R.; Davis, V.M.; Steckel, L.E.; Walsh, M.J. Tall waterhemp (Amaranthus tuberculatus) and Palmer amaranth (Amaranthus palmeri) seed production and retention at soybean maturity. Weed Technol. 2016, 30, 284-290. [CrossRef]

29. Bensch, C.N.; Horak, M.J.; Peterson, D. Interference of redroot pigweed (Amaranthus retroflexus), Palmer amaranth (A. palmeri), and common waterhemp (A. rudis) in soybean. Weed Sci. 2003, 51, 37-43. [CrossRef]

30. Massinga, R.A.; Currie, R.S.; Horak, M.J.; Boyer, J. Interference of Palmer amaranth in corn. Weed Sci. 2001, 49, 202-208. [CrossRef]

31. Bravo, W.; Leon, R.G.; Ferrell, J.A.; Mulvaney, M.J.; Wood, C.W. Differentiation of life-history traits among Palmer amaranth populations (Amaranthus palmeri) and its relation to cropping systems and glyphosate sensitivity. Weed Sci. 2017, 65, 339-349. [CrossRef]

32. Norsworthy, J.K.; Griffith, G.; Griffin, T.; Bagavathiannan, M.; Gbur, E.E. In-field movement of glyphosate-resistant Palmer amaranth (Amaranthus palmeri) and its impact on cotton lint yield: Evidence supporting a zero-tolerance threshold strategy. Weed Sci. 2014, 62, 237-249. [CrossRef] 